\title{
SDS-degrading bacteria attach to riverine sediment in response to the surfactant or its primary biodegradation product dodecan-1-ol
}

\author{
Julian R. Marchesi, ${ }^{1} \nmid$ Sarah A. Owen, ${ }^{1}$ Graham F. White, ${ }^{1}$ W. Alan House ${ }^{2}$ \\ and Nicholas J. Russell ${ }^{1}$
}

Author for correspondence: Julian R. Marchesi. Tel: +44222 874000. Fax: +44222874305. e-mail: marchesi@,cardiff.ac.uk

1 School of Molecular and Medical Biosciences, Biochemistry Unit, University of Wales Cardiff, PO Box 911 , Cardiff CF1 3US, UK

2 Institute of Freshwater Ecology, River Laboratory, East Stoke, Wareham, Dorset BH20 6BB, UK

\begin{abstract}
A laboratory-scale river microcosm was used to investigate the effect of the anionic surfactant sodium dodecyl sulphate (SDS) on the attachment of five Pseudomonas strains to natural river-sediment surfaces. Three of the Pseudomonas strains were chosen for their known ability to express alkylsulphatase enzymes capable of hydrolysing SDS, and the other two for their lack of such enzymes. One strain from each category was isolated from the indigenous bacterial population present in the river sediment used; other isolates were from soil or sewage. The alkylsulphatase phenotypes were confirmed by gel zymography of cell extracts. Addition of SDS to mixed suspensions of river sediment with any one of the biodegradation-competent strains stimulated the attachment of bacteria to the sediment particles. In contrast, the attachment of biodegradation-incompetent strains was weak and, moreover, was unaffected by SDS. The SDS-stimulated attachment for competent organisms coincided with rapid biodegradation of the surfactant. The primary intermediate of SDS biodegradation, dodecan-1-ol, accumulated transiently, and the numbers of attached bacteria correlated closely with the amount of dodecan-1-ol present. Direct addition of dodecan-1-ol also stimulated attachment but the effect was more immediate compared with SDS, when there was a lag period of approximately $2 \mathrm{~h}$. To account for these observations, a model is proposed in which SDS stimulates the attachment of biodegradation-competent bacteria through its conversion to dodecan-1-ol, and it is hypothesized that the observed reversibility of the attachment is due to the subsequent removal of dodecan-1-ol by further bacterial metabolism.
\end{abstract}

Keywords: biodegradation, sodium dodecyl sulphate (SDS), dodecan-1-ol, biofilm, surfactant

\section{INTRODUCTION}

Epilithic bacteria are known to make major contributions to heterotrophic activity in rivers (Costerton $e t$ al., 1987). Consequently, alterations in the partitioning of bacteria between the solid (e.g. sediment) and the bulk aqueous phases have implications for modelling the translocation and fate of pollutants in rivers and estuaries. Compounds most likely to influence such a partitioning are those

+Present address: School of Pure and Applied Biology, University of Wales Cardiff, PO Box 915, Cardiff CF1 3TL, UK.

Abbreviation: MBAS, methylene blue active substance. which are surface active. Several authors have investigated the effects of surfactants on the adhesion of bacteria at water-oil and water-solid interfaces. The observed effects depend on the hydrophobic-hydrophilic nature of the surface in contact with the water phase, and on the nature of the surfactant. Generally surfactants, especially the non-ionic ones, have been found not only to inhibit microbial adhesion to hydrophobic surfaces such as hydrocarbons (Rosenberg et al., 1983) and plastics (Klotz et al., 1985; McCourtie et al., 1985; Humphries et al., 1986), but also to stimulate detachment (McEldowney \& Fletcher, 1986). Similar inhibitory effects of surfactants were observed for the attachment of estuarine and marine bacteria to hydrophobic surfaces, although attachment to 
hydrophilic surfaces was much less sensitive (Paul \& Jeffrey, 1985; Humphries et al., 1987). At the concentrations used, the surfactants did not affect bacterial growth, so that toxicity was eliminated as the mode of action in favour of disruption of hydrophobic interactions. More recently, the cationic surfactant cetyl pyridinium chloride was shown to enhance microbial adhesion to hexadecane by diminishing surface charge and increasing cell-surface hydrophobicity (Goldberg et al., 1990).

In terms of scale of industrial production, the anionic surfactants are the most important and therefore are potentially significant environmental pollutants. In some situations (e.g. surfactant enhancement of soil-hydrocarbon bioremediation, or application of agrochemical sprays typically containing $>1000$ p.p.m. surfactant), the concentration of surfactants in groundwater or run-off may easily exceed 10 p.p.m. We have shown using a laboratory-scale river microcosm that biodegradable surfactants such as sodium dodecyl sulphate (SDS) promote the reversible attachment of an indigenous mixed culture of bacteria to river sediment (Marchesi et al., 1991b). In contrast, non-biodegradable surfactants and non-surfactant carbon sources did not stimulate bacterial attachment in the same test system (Marchesi et al., 1991b). In those experiments the only bacteria present were members of the indigenous mixed population which remained associated with the sediment during its preparation; although the phase of surface attachment coincided with surfactant biodegradation, it was not possible to determine whether it was only biodegradation-competent bacteria which attached to the sediment. Another question which arose from that study was whether attachment was stimulated by the parent surfactant (SDS) per se or by its primary biodegradation product dodecan-1-ol. In order to investigate these aspects we now report the results of microcosm experiments using SDS and dodecan-1-ol with pure cultures of pseudomonads, three of which could biodegrade SDS and two which could not, including representatives of each type isolated from the sediment.

\section{METHODS}

Bacterial strains. The five Pseudomonas strains used are listed in Table 1. Pseudomonas C12B (NCIMB 11753) was isolated by Payne \& Feisal (1963) from soil at a sewage outfall, while Pseudomonas ATCC 19151 was isolated by Hsu (1963) from untreated sewage; both are capable of biodegrading SDS. A third SDS-degrader, Pseudomonas BPS-D, was isolated from the Botany Pond sediment used in this and a previous study (Marchesi et al., 1991b). The two pseudomonads which were unable to metabolize SDS were a strain of Pseudomonas syringae isolated from soil by Crescenzi (1983) and Pseudomonas BPS-ND isolated from Botany Pond sediment as part of this study.

The indigenous pseudomonads were isolated by plating $0.1 \mathrm{ml}$ of Botany Pond sediment ( $1 \mathrm{mg}$ dry wt $\mathrm{ml}^{-1}$ ) on Bacto-agar (Difco; $2 \%, \mathrm{w} / \mathrm{v}$ ) plates containing $0.07 \%$ (w/v) SDS as the sole carbon source. The surfactant crystallizes out of solution at room temperature, giving the agar an opaque appearance. After incubation at $30^{\circ} \mathrm{C}$ for $24 \mathrm{~h}$, the plates were allowed to cool to room temperature, when SDS degraders showed as colonies surrounded by a clear halo. Single colonies were repurified on SDS-agar plates and tested for growth in liquid culture on $0.02 \%(\mathrm{w} / \mathrm{v})$ SDS in basal salts; the concomitant breakdown of SDS was monitored using the methylene-blue-active-substance (MBAS) assay (vide infra).

Strains incapable of biodegrading SDS could also be isolated from the same set of isolation plates, because Bacto-agar contains sufficient organic impurities to support their growth. Such non-degraders were easily distinguishable because they formed colonies lacking the clear halo, and on subculture into liquid medium containing SDS as the sole carbon source they failed to grow.

Having established that the Botany Pond isolates were Gramnegative, motile rods, they were further identified as belonging to the genus Pseudomonas using the Analytical Profile Index (API) 20B system (API Products). A representative constitutive degrader and non-degrader were selected on the basis of their rapid growth on SDS and nutrient broth, respectively.

Growth and harvesting of cultures for use in microcosm experiments. All bacterial strains were maintained on nutrient agar (Difco; $2 \%, \mathrm{w} / \mathrm{v}$ ) slopes, which were used to inoculate starter cultures of $50 \mathrm{ml}$ nutrient broth (Difco; $0.8 \%, \mathrm{w} / \mathrm{v}$ ) in $100 \mathrm{ml}$ Erlenmeyer flasks. The starter cultures were incubated overnight at $25^{\circ} \mathrm{C} / 150$ r.p.m. in an orbital incubator, and $0.2 \mathrm{ml}$ used to inoculate $200 \mathrm{ml}$ nutrient broth in $500 \mathrm{ml}$ Erlenmeyer flasks, which were incubated at $25^{\circ} \mathrm{C} / 150$ r.p.m. in an orbital incubator for $15 \mathrm{~h}$.

Bacteria were harvested by centrifuging cultures at $5000 \boldsymbol{g}_{\mathrm{av}}$ for $10 \mathrm{~min}$ at $25^{\circ} \mathrm{C}$. The bacterial pellet was washed free of residual growth medium by resuspension in $100 \mathrm{ml}$ sterile distilled water followed by centrifugation at $4000 \mathrm{~g}_{\mathrm{av}}$ for $5 \mathrm{~min}$ at $25^{\circ} \mathrm{C}$. This washing procedure was repeated and the bacterial pellet finally resuspended in $10 \mathrm{ml}$ sterile basal salts solution. Bacteria were enumerated by epifluorescence microscopy (vide infra).

Epifluorescence microscopy. A portion $(20 \mu \mathrm{l})$ of washed bacterial suspension was diluted 250 -fold in filter-sterilized $(0.2 \mu \mathrm{m}$ pore size) distilled water, and $20 \mu \mathrm{l}$ of this was fixed in glutaraldehyde $(2.5 \%, \mathrm{v} / \mathrm{v}$, final concentration), filtered through prestained Nucleopore polycarbonate black filters $(0 \cdot 2 \mu \mathrm{m}$ pore size), and prepared for epifluorescence microscopy analysis according to the method of Clarke \& Joint (1986). Epifluorescence microscopy was performed using a Zeiss standard 15 microscope, equipped with a IV-FL epifluorescence condenser, BP450/490 exciter filter, FT 510 dichromatic beam splitter and an LP 520 barrier filter. Ten fields of view were enumerated to obtain a mean value of cell density for the washed bacterial suspension.

For samples taken from the microcosm (vide infra) in which sediment was present, estimation of the relative numbers of bacteria which were free-living and attached to the sediment was performed using the method of Clarke \& Joint (1986).

Methylene-blue-active-substance assay. SDS was quantified using the MBAS assay for anionic surfactants of Hayashi (1975), as modified by Thomas (1987). This assay was used to determine SDS biodegradation in the microcosm as described in Marchesi et al. (1991b). Data points were fitted to a curve of best fit according to Anderson et al. (1990).

Use of laboratory river microcosm to study surfactant biodegradation. The computer-controlled laboratory microcosm used to investigate the influence of surfactants on bacterial attachment to a riverine (Botany Pond) sediment has been 
Table 1. Sources of bacterial strains used in the present study

\begin{tabular}{|llll|}
\hline Bacterium & \multicolumn{1}{c}{ Source } & \multicolumn{1}{c|}{$\begin{array}{c}\text { Enrichment } \\
\text { substrate }\end{array}$} & \multicolumn{1}{c|}{ Reference } \\
\hline Pseudomonas C12B (NCIMB 11753) & Soil & SDS & Payne \& Feisal (1963) \\
Pseudomonas ATCC 19151 & Sewage & SDS & Hsu (1963) \\
Pseudomonas syringae & Soil & Propyl-2-sulphate & Crescenzi (1983) \\
Pseudomonas BPS-D & River sediment & SDS & Marchesi et al. (1991b) \\
Pseudomonas BPS-ND & River sediment & Non-specific & Present study \\
\hline
\end{tabular}

described by Marchesi et al. (1991b). The same conditions were used in the experiments reported here, except that the $96 \mathrm{~h}$ equilibration time prior to surfactant addition was omitted in the experiments using pure cultures. The sequence of additions to the microcosm was: $10 \mathrm{mM} \mathrm{NaHCO} / \mathrm{CO}_{2}$ buffer $\mathrm{pH} 7 \cdot 6$, bacterial suspension (final density $2 \times 10^{7}$ cells $\mathrm{ml}^{-1}$ ), river sediment $(0 \cdot 1 \%, w / v)$, and 20 p.p.m. SDS or 20 p.p.m. dodecan-1-ol (final concentrations); 5 min was allowed between each addition to allow mixing, and the addition of river sediment was regarded as the zero time point. The microcosm temperature was maintained at $25^{\circ} \mathrm{C}$ and at $\mathrm{pH} 7 \cdot 6 \pm 0 \cdot 1$ by constant infusion of $\mathrm{CO}_{2}$.

Statistical tests. To determine whether there was a statisticallysignificant difference between bacterial numbers in samples, they were compared using Student's $t$ test with a $95 \%$ confidence level. This test was used, for example, to compare the standard error of the means of paired samples from incubations with or without SDS (Harper, 1965). To make the test as objective as possible the largest mean value for the experiment without SDS was compared to its parallel mean value in the experiment with SDS. To balance this analysis, the greatest mean value in the experiment with SDS was compared to its corresponding value in the experiment without SDS.

Gel zymography of alkylsulphatases. Cultures $(400 \mathrm{ml})$ in 11 Erlenmeyer flasks were harvested by centrifugation at $9000 \boldsymbol{g}_{\mathrm{av}}$ for $10 \mathrm{~min}$ at $4{ }^{\circ} \mathrm{C}$. The bacterial pellet was washed by resuspension in $20 \mathrm{ml} 50 \mathrm{mM}$ Tris/ $\mathrm{HCl}$ buffer, $\mathrm{pH} 7.5$ at $4{ }^{\circ} \mathrm{C}$, and centrifugation at $4000 \mathrm{~g}_{\mathrm{av}}$ for $5 \mathrm{~min}$ at $4{ }^{\circ} \mathrm{C}$. This washing procedure was repeated once and the bacterial pellet finally resuspended in $5 \mathrm{ml}$ of $50 \mathrm{mM}$ Tris/ $\mathrm{HCl}$ buffer, $\mathrm{pH} 7 \cdot 5$ at $4{ }^{\circ} \mathrm{C}$.

Bacteria were disrupted by three passages through a chilled French pressure cell (American Instruments) operating at $120 \mathrm{MPa}$. The broken cell suspension was centrifuged at $27000 \boldsymbol{g}_{\text {av }}$ at $4{ }^{\circ} \mathrm{C}$ for $30 \mathrm{~min}$; the supernatant was removed and centrifuged at $100000 \mathrm{~g}_{\mathrm{av}}$ for $40 \mathrm{~min}$ at $4{ }^{\circ} \mathrm{C}$ and the final supernatant retained for gel zymography using a modification of the original method of Payne \& Painter (1971) as described by Dodgson et al. (1974). Non-denaturing rod-gel electrophoresis was performed in $6.8 \%(\mathrm{w} / \mathrm{v})$ Acrylogel gels cast in glass rods $(80 \mathrm{~mm} \times 5 \mathrm{~mm})$ with a Bio-Rad constant current/voltage DC power supply. Samples of cell-free extract $(100 \mu \mathrm{l})$ were mixed with $20 \mu \mathrm{l} 20 \%(\mathrm{v} / \mathrm{v})$ glycerol containing $0.4 \% \quad(\mathrm{w} / \mathrm{v})$ bromophenol blue. Electrophoresis was performed using a current of $2 \mathrm{~mA}$ per gel and stopped when the tracker dye was $5 \mathrm{~mm}$ from the bottom of the gels. The tubes were removed, and the gels extruded and cut at the tracker dye. The gels were incubated in $50 \mathrm{mM}$ Tris $/ \mathrm{HCl}$ buffer, $\mathrm{pH} 7 \cdot 5$, containing $10 \mathrm{mM}$
SDS to detect primary alkylsulphatases; the location of alkylsulphatase enzyme(s) was marked by the generation of white band(s) of insoluble dodecan-1-ol in the gel.

Gas-liquid chromatography. Samples removed from the microcosm for GLC analysis were centrifuged at $2800 \mathrm{~g}_{\mathrm{av}}$ for $5 \mathrm{~min}$; the supernatant was discarded (preliminary experiments demonstrated that no dodecan-1-ol was present in this supernatant) and $1 \mathrm{ml}$ methanol added to the wet sediment pellet, which was resuspended by ultrasonication and transferred to a glass tube. The resuspended sediment was extracted with three aliquots $(2 \mathrm{ml})$ of $n$-hexane, and the pooled extracts evaporated to dryness under nitrogen gas. The residue was redissolved in $0.25 \mathrm{ml}$ dry light petroleum (b.p. $60-80^{\circ} \mathrm{C}$; dried over molecular sieve, $0.4 \mathrm{~nm}$ pore size) for GLC analysis.

GLC was performed using a Perkin Elmer 8310 gas chromatograph equipped with a $1.5 \times 5 \mathrm{~mm}$ (i.d.) glass column packed with $10 \%$ (w/w) Carbowax 20M on 80-100 mesh Supelcoport (Supelcoport, Bellefont). Separations were performed isothermally at $190^{\circ} \mathrm{C}$ with the flame ionization detector and injector temperatures set at $250^{\circ} \mathrm{C}$. The carrier gas was nitrogen at an inlet pressure of $85 \mathrm{kPa}\left(35 \mathrm{ml} \mathrm{min}^{-1}\right)$. The gas chromatograph was calibrated with authentic decan-1-ol, dodecan-1-ol and tetradecan-1-ol dissolved in anhydrous light petroleum (b.p. $60-80^{\circ} \mathrm{C}$; dried over molecular sieve, $0.4 \mathrm{~nm}$ pore size). Sample peaks were identified by their relative retention times and co-chromatography, and quantified by calculation of peak areas.

\section{RESULTS}

\section{Alkylsulphatase content of bacterial isolates}

The five Pseudomonas strains were grown on nutrient broth $(0.3 \%, \mathrm{w} / \mathrm{v})$ and their content of alkylsulphatase enzyme(s) tested using gel zymography, which indicated that only Pseudomonas $\mathrm{C} 12 \mathrm{~B}$ possessed a constitutive alkylsulphatase. When the strains were grown on nutrient broth supplemented with $0 \cdot 01 \%$ (w/v) SDS, Pseudomonas BPS-D developed one band and Pseudomonas C12B developed a second band distinct from the constitutive alkylsulphatase on the gels (data not shown). Pseudomonas sp. ATCC 19151 exhibited alkylsulphatase activity only when cultured in basal salts solution with $\operatorname{SDS}(1.0 \%$, $\mathrm{w} / \mathrm{v}$ ) as the sole carbon source. The two pseudomonads incapable of degrading SDS, $P$. syringae and Pseudomonas BPS-ND, did not show alkylsulphatase activity under any of the cultural conditions used. 


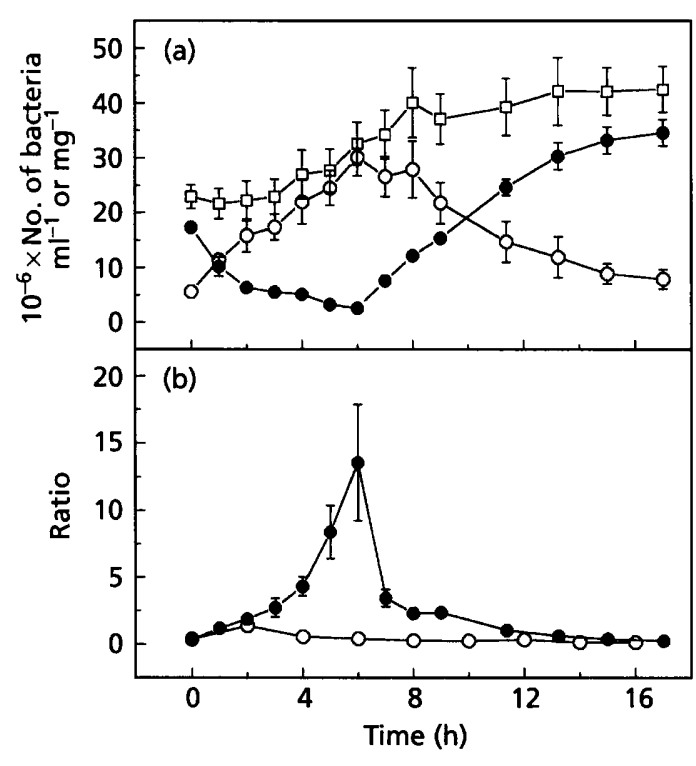

Fig. 1. Effect of SDS on the attachment of Pseudomonas C12B to Botany Pond sediment $(0.1 \%, w / v)$ in a laboratory microcosm. (a) Total bacterial numbers $(\square)$, attached bacterial numbers $(O$ and free-living bacterial numbers $(\boldsymbol{O})$. (b) The ratio of attached to free-living bacterial numbers is shown for Pseudomonas $\mathrm{C} 12 \mathrm{~B}$ incubated without $(O)$ and with $(O)$ the inclusion of 20 p.p.m. SDS at time zero. Error bars represent $95 \%$ confidence limits.

\section{Effect of surfactant on the distribution of bacterial strains between the sediment and aqueous phases in the microcosm}

The addition of SDS to mixed suspensions of Pseudomonas $\mathrm{C} 12 \mathrm{~B}$ and river sediment resulted in a significant $(P<0.05)$ increase in the numbers of bacteria attached to river sediment, which was accompanied by a decrease in the free-living bacteria during a time when there was little increase in total bacterial numbers (Fig. 1a). After $6 \mathrm{~h}$, there was a subsequent increase in free-living (and total) bacterial numbers and a decrease in the numbers of attached bacteria (Fig. 1a). This change in the bacterial populations resulted in there being a sharp peak in the ratio of attached to free Pseudomonas $\mathrm{C} 12 \mathrm{~B}$ centred on $6 \mathrm{~h}$ after the addition of SDS (Fig. 1b). In a control experiment in which addition of SDS was omitted, there was no significant change in the ratio of attached to freeliving bacteria (Fig. 1b). Data in Fig. 1(b) are reproduced in Fig. 2(a) for comparison with corresponding data for other isolates tested in the same way (Fig. $2 \mathrm{~b}-\mathrm{e}$ ). For Pseudomonas ATCC 19151 (Fig. 2b) and Pseudomonas BPS$\mathrm{D}$ (Fig. 2c) there was a similar increase in the ratio of attached to free-living bacteria when SDS was added to the microcosm, with peak values centred on 4 and $2 \mathrm{~h}$ respectively. Attachment maxima were not observed in the absence of added surfactant. The attachment of all three SDS-degrading strains of bacteria coincided with the rapid disappearance of the surfactant (Fig. $2 \mathrm{f}-\mathrm{h}$ ). In marked contrast, for P. syringae or Pseudomonas BPS-ND, which are unable to biodegrade SDS, there was no observable change in the ratio of attached to free-living bacteria during the period immediately after the addition of SDS to the microcosm (Fig. 2d, e), and the initial profiles were very similar to those observed in the absence of added SDS. In the experiments with added SDS, the ratio did not increase until 14-16 h after SDS addition, and the surfactant disappeared slowly from the micro$\operatorname{cosm}$, with $>65 \%$ of the original concentration remaining after $20-24$ h (Fig. 2i, j). A similarly late increase in the ratio was observed when indigenous bacteria on sediment were incubated in the presence of SDS (data not shown).

\section{Dodecan-1-ol formation during SDS biodegradation}

Following the addition of SDS to the microcosm containing Pseudomonas $\mathrm{C} 12 \mathrm{~B}$ and sediment, samples were removed and analysed for content of dodecan-1-ol. Production of dodecan-1-ol (Fig. 3a) coincided with the disappearance of SDS (Fig. 2f), reaching a maximum when the rate of SDS degradation was at its fastest $(6 \mathrm{~h})$. Thereafter the concentration of dodecan-1-ol decreased, most likely as a result of further bacterial metabolism and growth (see Fig. 1a). During both the increasing and decreasing phases shown in Fig. 3(a), the concentration of dodecan-1-ol was closely correlated $(r=0.93$, for $P=0.05$ ) with bacterial attachment (Fig. 3b).

The coincidence of SDS biodegradation and bacterial attachment observed in the present work (Fig. 1) had also been observed previously (Marchesi et al., 1991b) in microcosm experiments in which SDS was used in the absence of added known degraders, to stimulate attachment of indigenous bacteria. To determine whether dodecan-1-ol production occurred under those conditions, SDS was added to sediment alone in the microcosm (i.e. without the addition of known degraders) and the progress of SDS disappearance and dodecan-1-ol production were monitored. In this experiment, the concentration of sediment was increased from the usual $0.1 \%$ to $2.5 \%(\mathrm{w} / \mathrm{v})$ in order to make the time-frame of biodegradation similar to that observed in the other experiments employing added degraders. Under these conditions, the degradation of SDS by indigenous bacteria was accompanied by simultaneous appearance of dodecan1-ol. By $22 \mathrm{~h}$, all the SDS and dodecan-1-ol had disappeared (data not shown). Presterilization of the sediment by autoclaving abolished SDS biodegradation and dodecan-1-ol production, and separate extractions of the sediment and of the stock solution of SDS revealed that the separate components were themselves devoid of dodecan-1-ol.

\section{Effect of dodecan-1-ol on the distribution of bacterial strains between the sediment and aqueous phases in the microcosm}

The direct addition of dodecan-1-ol to the microcosm containing Pseudomonas $\mathrm{C} 12 \mathrm{~B}$ and sediment stimulated attachment of bacteria to the sediment (Fig. 4). The attachment profile was similar to that observed for SDS 


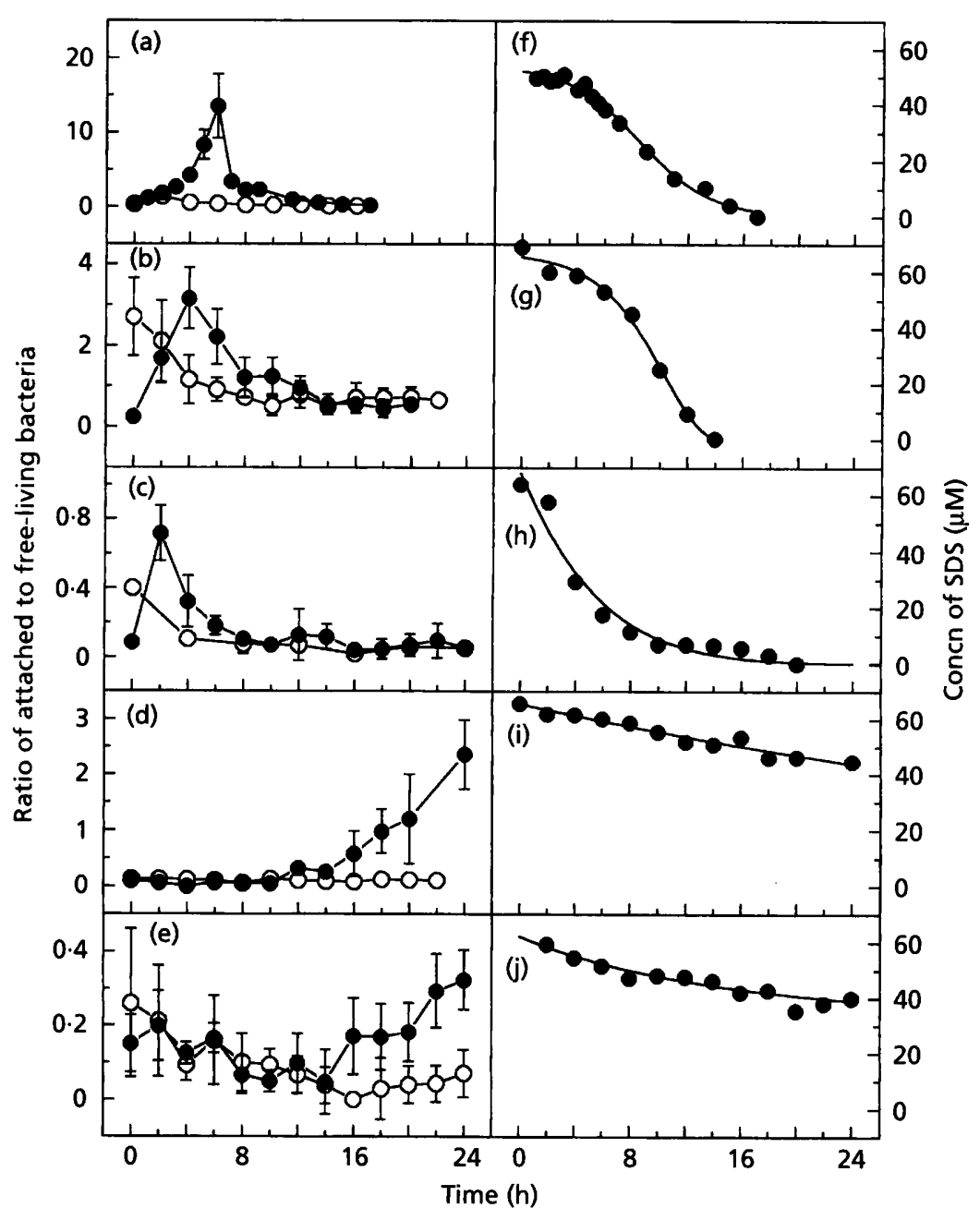

Fig. 2. Ratio of attached to free-living bacterial numbers (a-e) and the disappearance of SDS $(f-j)$ for each bacterial strain incubated separately with Botany Pond sediment $(0.1 \%, w / v)$ in a laboratory microcosm; (a, f) Pseudomonas C12B; (b, g) Pseudomonas ATCC 19151; (c, h) Pseudomonas BPS-D; (d, i) P. syringae; $(e, j)$ Pseudomonas BPS-ND. O, Control incubations without SDS; 0 , incubations with $69 \mu \mathrm{M}$ SDS. The error bars represent $95 \%$ confidence limits.

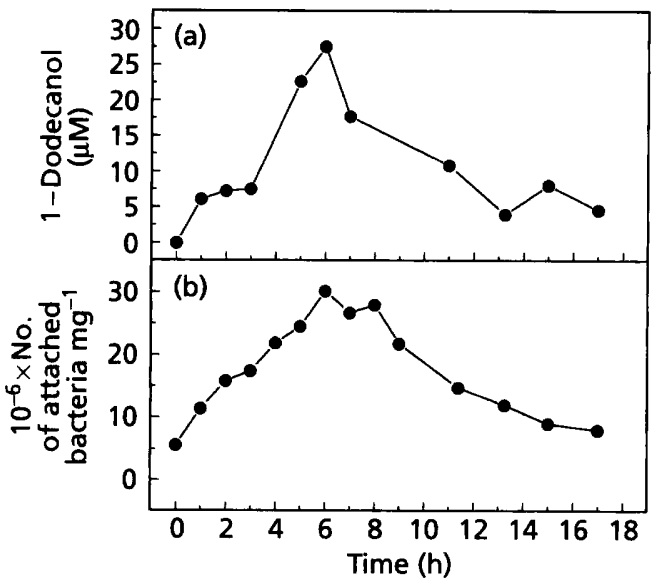

Fig. 3. (a) Production of dodecan-1-ol and (b) attachment of Pseudomonas $\mathrm{C} 12 \mathrm{~B}$ during incubation with Botany Pond sediment in the microcosm.

except that it occurred earlier, peaking at $3 \mathrm{~h}$ after the addition of dodecan-1-ol.

When dodecan-1-ol was added to sediment which had

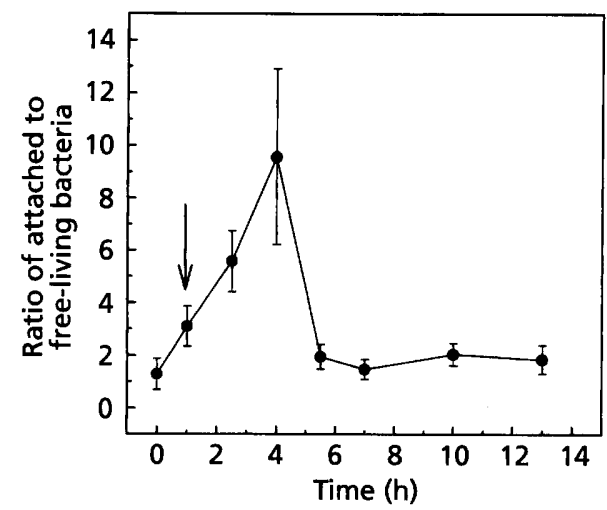

Fig. 4. Effect of dodecan-1-ol on attachment of Pseudomonas C $12 \mathrm{~B}$ to Botany Pond sediment $(0.1 \%, w / v)$. Sediment was preequilibrated for $55 \mathrm{~min}$ in the microcosm before addition (arrow) of 20 p.p.m.-dodecan-1-ol.

been pre-equilibrated alone in the microcosm (Marchesi et al., 1991b), there was a significant increase in the attachment of indigenous bacteria (Fig. 5). Although the ratio of attached to free-living bacteria was lower than for 


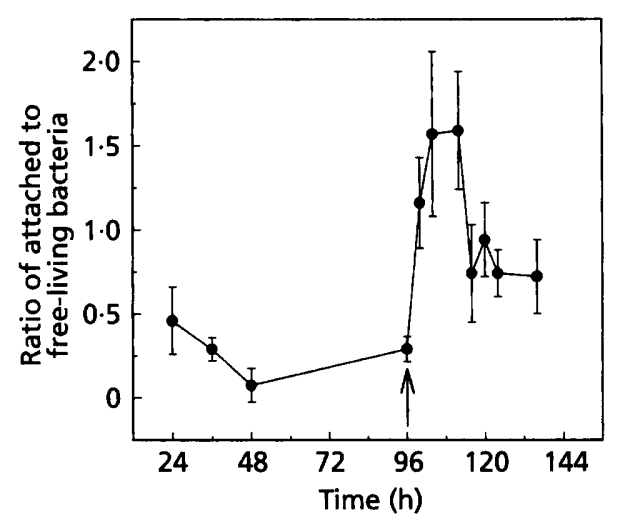

Fig. 5. Effect of dodecan-1-ol on attachment of indigenous bacteria to Botany Pond sediment $(0.1 \%, w / v)$. Sediment was pre-equilibrated in the microcosm for $96 \mathrm{~h}$ before addition (arrow) of dodecan-1-ol.

Pseudomonas $\mathrm{C} 12 \mathrm{~B}$ under similar conditions (Fig. 4), the fold-increase was similar and the ratios in Fig. 5 were similar to those achieved previously for the stimulation of attachment of indigenous bacteria by SDS (Marchesi $e t$ al., 1991b).

\section{DISCUSSION}

Previous work has shown that addition of biodegradable alkyl sulphate surfactants stimulated the attachment of bacteria to sediment in a laboratory microcosm (Marchesi et al., 1991b). Despite the fact that the bacteria detached once the surfactant had been biodegraded, the effect was not simply a result of the surface-active nature of the compound, since non-biodegradable alkyl sulphate homologues of different chain length and other nondegradable anionic surfactants had little or no effect on bacterial attachment. Moreover, the effect was not due to increased bacterial metabolism (the surfactant is a carbon and energy source), since non-surfactant growth substrates also failed to stimulate attachment (Marchesi $e t$ al., 1991b). Therefore, a reasonable working hypothesis was that a product of surfactant metabolism, rather than the surfactant itself, was responsible for promoting surface attachment. The initial biodegradation products of primary alkyl sulphates are primary alcohols (Thomas \& White, 1989), which are readily metabolizable by universal enzymes of intermediary metabolism (White \& Russell, 1993). Thus primary biodegradation of SDS is known to yield dodecan-1-ol, and so attention was focussed on this compound in the experiments reported here.

The indigenous population of bacteria on the Botany Pond sediment is probably comprised of both SDS degraders and non-degraders. In the experiments of Marchesi et al. (1991b) in which surfactant biodegradation by indigenous bacteria on sediment was studied, it was not possible to know whether the attaching bacteria were biodegradation-competent or -incompetent. The present study aimed to resolve this question by adding pure cultures of known degraders or non-degraders to the microcosm, including a representative example of each category isolated from the sediment. It was deemed important to include natural isolates from the sediment, since these represent those encountered in the natural aquatic environment from which the sediment was isolated and moreover they might be specifically adapted to attach to its surfaces. Exogenous isolates were added to the microcosm in numbers which were tenfold in excess over that of the indigenous bacteria, in order to ensure that the effects observed were reflective of the exogenously-added strain. This approach was preferred to one in which the indigenous bacteria were killed (e.g. by autoclaving) or removed from the sediment surface (e.g. by chemical treatment), because such procedures were found to alter the adsorption properties of the sediment.

The results showed that the immediate phase of attachment occurred only when the SDS was broken down by a biodegradation-competent strain. The absence of a further increase in the numbers of bacteria during the initial rapid attachment phase indicated that the phenomenon was not the result of growth of the attached population but reflected bacterial traffic between bulk liquid and sediment surface. A similar observation has been reported for the attachment of several Pseudomonas aeruginosa strains to stainless steel by Vanhaecke $e t$ al. (1990), who showed that attachment was rapid and that those strains which were more hydrophobic, attached to a greater extent. Previous work has shown that SDS adsorbs rapidly to Botany Pond sediment (Marchesi et al., 1991a). Consequently, in the present experiments, the initial attachment may have been simply a response to the accumulation of hydrophobic surface-active SDS molecules concentrated at the solid-liquid interface (Marshall \& Cruickshank, 1973; van Loosdrecht et al., 1987). However, this surfactant is biodegradable, and the accumulation of biodegradation-competent bacteria at the surface would have resulted in an increase in the production of the primary biodegradation intermediate, dodecan-1-ol (Thomas \& White, 1989). A consequence of the release of dodecan-1-ol, which is particularly hydrophobic, is that it probably promoted bacterial attachment more strongly than did SDS. Evidence for this is presented in Fig. 3, which shows that the production of dodecan-1-ol from SDS mirrored closely the attachment of the constitutive SDS-degrading bacterium Pseudomonas $\mathrm{C} 12 \mathrm{~B}$ when added exogenously to the sediment in a laboratory microcosm. The period of maximum attachment coincided with that of maximum production of dodecan-1-ol; the alcohol was further metabolized and, as its concentration in the microcosm declined, the bacteria detached from the sediment surface. The timing of the peak of attachment and the SDS breakdown was found to be very similar for two other strains, Pseudomonas ATCC 19151 and Pseudomonas BPS-D, each of which was shown to contain an inducible alkylsulphatase enzyme active towards SDS. This cycle of events (SDS adsorption $\rightarrow$ bacterial attachment $\rightarrow$ dodecan-1-ol production $\rightarrow$ more bacterial attachment) results in a positive feedback loop, which is broken when the rate of dodecan-1-ol metabolism 
exceeds that of its formation. Once the concentration of dodecan-1-ol began to decline, stimulus for attachment declined so that bacteria became detached from the sediment surface and resumed a planktonic existence. The reversible attachment of bacteria in response to adsorbed nutrients has been termed 'chemoadherence' (Lawrence et al., 1987).

All three SDS degraders used in this study produced inducible alkylsulphatases. However, cultures for the microcosm experiments were not in fact preinduced by growth on SDS because residual surfactant and dodecan1-ol from growth flasks could have complicated the analysis of microcosm data. Instead cultures were grown on nutrient broth, repeatedly washed, and uninduced cells added directly to the microcosm. The time typically taken to produce an inducible enzyme (minutes) is short relative to the time-scale of attachment and SDS biodegradation in the microcosm (hours).

The lack of attachment of bacteria which were unable to metabolize the surfactant can be explained by the absence of the establishment of the feedback loop. Clearly the surface-active properties of SDS alone are insufficient to promote extensive bacterial attachment, which occurs only when there is surfactant biodegradation and concomitant accumulation of dodecan-1-ol in situ. The observation that the non-degraders showed a late and slow phase of attachment may be explained by the hydrolysis of SDS by indigenous degraders slowly releasing dodecan-1-ol at the sediment surface and stimulating either metabolism and growth of those indigenous degraders at the sediment surface, or attachment of planktonic non-degraders.

Several authors have noted that the biodegradation of adsorbed hydrophobic organics (e.g. petroleum and oil derivatives) in soil and sediment systems may be markedly stimulated by the addition of synthetic surfactants. This has usually been attributed to solubilization and mobilization of the substrate from its adsorbed state into one of greater 'bioavailability' (Aronstein \& Alexander, 1992, 1993; Oberbremer et al., 1990). In some instances, however, acceleration of hydrocarbon biodegradation has been observed even under conditions where no solubilization or mobilization of the substrate can be demonstrated (Aronstein et al., 1991). The results presented here suggest an alternative scenario to account for these observations, namely that the addition of biodegradable surfactant stimulates attachment of biodegradation-competent bacteria, thereby bringing bacteria and substrate together at the sediment surface rather than in the bulk non-adsorbed phase. The notion that some competent bacteria might biodegrade pollutants more efficiently when surface-associated is supported by the findings of Guerin \& Boyd (1992). These authors compared two naphthalene-degrading isolates and showed that for one, the rate and extent of naphthalene mineralization was restricted by the presence of soil particles, whereas for the other, the rate and extent of biodegradation exceeded predicted values and resulted in enhanced removal of naphthalene from soils. The present study shows that preference of pollutant-degraders for the planktonic or sessile states may be not only organismspecific (Guerin \& Boyd, 1992) but also influenced by surface-active agents and their degradation products present in the system.

\section{REFERENCES}

Anderson, D. J., Day, M. J., Russell, N. J. \& White, G. F. (1990). Die-away kinetic analysis of the capacity of epilithic and planktonic bacteria from clean and polluted river water to biodegrade sodium dodecyl sulphate. Appl Environ Microbiol 56, 758-763.

Aronstein, B. N. \& Alexander, M. (1992). Surfactants at low concentrations stimulate biodegradation of sorbed hydrocarbons in samples of aquifer sands and soil slurries. Environ Toxicol Chem 11, 1227-1233.

Aronstein, B. N. \& Alexander, M. (1993). Effect of a non-ionic surfactant added to the soil surface on the biodegradation of aromatic hydrocarbons within soil. Appl Microbiol Biotechnol 39, 386-390.

Aronstein, B. N., Calvillo, Y. M. \& Alexander, M. (1991). Effects of surfactants at low concentrations on the desorption and biodegradation of sorbed aromatic hydrocarbons in soil. Environ Sci Technol 25, 1728-1731.

Clarke, K. R. \& Joint, I. R. (1986). Methodology for estimating numbers of free-living and attached bacteria in estuarine water. Appl Environ Microbiol 51, 1110-1120.

Costerton, J. W.s Cheng, K.-J., Geesey, G. G., Ladd, T. I., Nickel, J. C., Dasgupta, M. \& Marrie, T. J. (1987). Bacterial biofilms in nature and disease. Annu Rev Microbiol 41, 435-464.

Crescenzi, A. M. V. (1983). Microbial degradation of short chain alkyl sulphate esters. PhD Thesis, University of Wales.

Dodgson, K. S., Fitzgerald, J. W. \& Payne, W. J. (1974). Chemically defined inducers of alkylsulfatases present in Pseudomonas C12B. Biochem J 138, 53-62.

Goldberg, S., Konis, Y. \& Rosenberg, M. (1990). Effect of cetyl pyridinium chloride on microbial adhesion to hexadecane and polystyrene. Appl Environ Microbiol 56, 1678-1682.

Guerin, W. F. \& Boyd, S. A. (1992). Differential bioavailability of soil-sorbed naphthalene to two bacterial species. Appl Environ Microbiol 58, 1142-1152.

Harper, W. M. (1965). Statistics. London: Macdonalds \& Evans.

Hayashi, K. (1975). A rapid determination of sodium dodecyl sulfate with methylene blue. Anal Biocbem 67, 503-506.

Hsu, Y.-C. (1963). Detergent (SLS)-splitting enzyme from Pseudomonas. Nature 200, 1091-1092.

Humphries, M., Jaworzyn, J. F. \& Cantwell, J. B. (1986). The effect of a range of biological polymers and synthetic surfactants on the adhesion of a marine Pseudomonas sp. strain NCMB 2021 to hydrophilic and hydrophobic surfaces. FEMS Microbiol Ecol 38, 299-308.

Humphries, M., Jaworzyn, J. F., Cantwell, J. B. \& Eakin, A. (1987). The use of non-ionic ethoxylated and propoxylated surfactants to prevent the adhesion of bacteria to solid surfaces. FEMS Microbiol Lett 42, 91-101.

Klotz, S. A., Drutz, D. S. \& Zajic, J. E. (1985). Factors governing adherence of Candida species to plastic surfaces. Infect Immun 50, 97-101.

Lawrence, J. R., Delaquis, P. J., Korber, D. R. \& Caldwell, D. E. (1987). Behavior of Pseudomonas fluorescens within the hydrodynamic boundary layers of surface microenvironments. Microb Ecol 14, $1-14$. 
van Loosdrecht, M. C. M., Lyklema, J., Norde, W., Schraa, G. \& Zehnder, A. J. B. (1987). The role of bacterial cell wall hydrophobicity in adhesion. Appl Environ Microbiol 53, 1893-1897.

Marchesi, J. R., House, W. A., White, G. F., Russell, N. J. \& Farr, I. S. (1991a). A comparative study of the adsorption of linear alkyl sulphates and alkylbenzene sulphonates on river sediments. Colloids Surf 53, 63-78.

Marchesi, J. R., Russell, N. J., White, G. F. \& House, W. A. (1991b). Effects of surfactant adsorption and biodegradability on the distribution of bacteria between sediments and water in a freshwater microcosm. Appl Environ Microbiol 57, 2507-2513.

Marshall, K. C. \& Cruickshank, R. H. (1973). Cell surface hydrophobicity and the orientation of certain bacteria at interfaces. Arch Mikerobiol 91, 29-40.

McCourtie, J., MacFarlane, T. W. \& Samaranayake, L. P. (1985). Effect of chlorhexidine gluconate on the adherence of Candida species to denture acrylic. J Med Microbiol 20, 97-104.

McEldowney, S. \& Fletcher, M. (1986). Variability of the influence of physicochemical factors affecting bacterial adhesion to polystyrene substrate. Appl Environ Microbiol 52, 460-465.

Oberbremer, A., Müller-Hurtig, R. \& Wagner, F. (1990). Effect of the addition of microbial surfactants on hydrocarbon degradation in a soil population in a stirred reactor. Appl Microbiol Biotechno 32, 485-489.

Paul, J. H. \& Jeffrey, W. H. (1985). The effect of surfactants on the attachment of estuarine and marine bacteria to surfaces. Can $J$ Microbiol 31, 224-228.

Payne, W. J. \& Feisal, V. E. (1963). Bacterial utilization of dodecyl sulphate and dodecylbenzene sulfonate. Appl Microbiol 11, 339-344.

Payne, W. J. \& Painter, B. D. (1971). Resolution by acrylamide gel electrophoresis of alkyl sulphatases and alcohol dehydrogenases. Microbios 3, 199-206.

Rosenberg, E., Gottlieb, A. \& Rosenberg, M. (1983). Inhibition of bacterial adherence to hydrocarbons and epithelial cells by emulsan. Infect Immun 39, 1024-1028.

Thomas, O. R. T. (1987). Development of solid support systems for the degradation of surfactants. PhD Thesis, University of Wales.

Thomas, O. R. T. \& White, G. F. (1989). Metabolic pathway for the biodegradation of sodium dodecyl sulfate by Pseudomonas sp. C12B. Biotech Appl Biochem 11, 318-327.

Vanhaecke, J., Remon, J., Moors, M., Raes, F., de Rudder, D. \& van Peteghem, A. (1990). Kinetics of Pseudomonas aeruginosa adhesion to 304 and 316-L stainless steel: role of cell surface hydrophobicity. Appl Environ Microbiol 56, 788-795.

White, G. F. \& Russell, N. J. (1993). Biodegradation of anionic surfactants and related molecules. In Biochemistry of Microbial Degradation, pp. 143-177. Edited by C. Ratledge. London: Kluwer.

Received 3 May 1994; revised 6 July 1994; accepted 19 July 1994. 